\title{
The Growth and Geographical Variation of Nursing Home Self-Pay Prices
}

Sean Shenghsiu Huang, Richard A. Hirth, Jane Banaszak-Holl, Stephanie Yuan

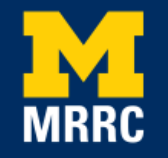

Project \#: R-UM17-14 


\title{
The Growth and Geographical Variation of Nursing Home Self-Pay Prices
}

\author{
Sean Shenghsiu Huang \\ Georgetown University \\ Richard A. Hirth \\ University of Michigan
}

Jane Banaszak-Holl

University of Michigan

Stephanie Yuan

Georgetown University

October 2017

\author{
Michigan Retirement Research Center \\ University of Michigan \\ P.O. Box 1248 \\ Ann Arbor, MI 48104 \\ www.mrrc.isr.umich.edu \\ (734) 615-0422
}

\section{Acknowledgements}

The research reported herein was performed pursuant to a grant from the U.S. Social Security Administration (SSA) funded as part of the Retirement Research Consortium through the University of Michigan Retirement Research Center Award RRC08098401-09. The opinions and conclusions expressed are solely those of the author(s) and do not represent the opinions or policy of SSA or any agency of the federal government. Neither the United States government nor any agency thereof, nor any of their employees, makes any warranty, express or implied, or assumes any legal liability or responsibility for the accuracy, completeness, or usefulness of the contents of this report. Reference herein to any specific commercial product, process or service by trade name, trademark, manufacturer, or otherwise does not necessarily constitute or imply endorsement, recommendation or favoring by the United States government or any agency thereof.

\section{Regents of the University of Michigan}

Michael J. Behm, Grand Blanc; Mark J. Bernstein, Ann Arbor; Shauna Ryder Diggs, Grosse Pointe; Denise Ilitch, Bingham Farms; Andrea Fischer Newman, Ann Arbor; Andrew C. Richner, Grosse Pointe Park; Ron Weiser, Ann Arbor; Katherine E. White, Ann Arbor; Mark S. Schlissel, ex officio 


\title{
The Growth and Geographical Variation of Nursing Home Self-Pay Prices
}

\begin{abstract}
Nursing home care is arguably the largest financial risk for the elderly without private or social insurance coverage. The annual out-of-pocket expenditure can easily exceed $\$ 70,000$. Despite the substantial financial burdens on the elderly, the understanding of nursing home self-pay prices is rather sparse due to data limitation. To bridge the gap in the literature, we collected a unique and longitudinal price dataset from eight states, spanning from 2005 to 2010, to advance the understanding of the determinants and geographical variations of nursing home price and price growth. Overall, nursing home prices have consistently outpaced the inflation of consumer prices, particularly in California and Oregon. We also see faster price growth in markets where they face stricter capacity constraints and have higher for-profit market shares. Organizational structures are also significantly associated with price variations. We find that nonprofit nursing homes have higher prices than for-profit nursing homes and that chain-affiliated nursing homes charge higher prices than nonchains counterparts.
\end{abstract}

\section{Citation}

Huang, Sean Shenghsiu, Richard A. Hirth, Jane Banaszak-Holl, and Stephanie Yuan. 2019. "The Growth and Geographical Variation of Nursing Home Self-Pay Prices.” Ann Arbor, MI: University of Michigan Retirement Research Center (MRRC) Working Paper, WP 2019-397. https://mrdrc.isr.umich.edu/publications/papers/pdf/wp397.pdf

\section{Authors' acknowledgements}

This research was supported by a grant from the Social Security Administration via the Michigan Retirement Research Center (UM17-14) and partly supported by the University of Michigan Hammel Award. We also thank state health agencies for making price data available. 


\section{Introduction}

Currently, there are more than 1.4 million people in the U.S. live in nursing homes, and it is estimated that a typical American at the age of 65 has a $35 \%$ chance of requiring nursing home care sometime in his or her lifetime (CDC, 2016). Institutionalized long-stay nursing home care is expensive. For example, the annual median price in 2010 was $\$ 110,025$ in the state of New York. ${ }^{1}$ Since most Americans do not purchase long-term care insurance to cover these expenses (Lin \& Prince 2013), out-of-pocket nursing home expenditure is a primary driver of precautionary savings and wealth accumulation (Kopecky \& Koreshkova 2014). The nonMedicaid eligible elderly pay for nursing home care out of savings and once depleted, they depend on Medicaid. As of 2016, Medicaid spent over \$51 billion per year on nursing home care (Medpac 2016).

\section{New Contribution}

Despite the substantial financial risk for the elderly, the understanding of nursing home private-pay prices is rather sparse due to data limitations. To bridge the gap in the literature, we evaluate unique price data that we collected for eight states and the years 2005 through 2010, combined with structural information of nursing facilities, to understand the association between organizational and market structures and private-pay prices. In particular, we are interested in whether for-profit (FP) ownership, chain affiliation, market concentration, and capacity constraints have significant associations with the level and growth of nursing home private-pay prices. Though our findings are not necessarily causal, we expect the results to facilitate a better use of the elderly's assets and wealth, inform policies enhancing the value of nursing home care,

\footnotetext{
${ }^{1}$ Based on authors' calculation.
} 
improve the sustainability of social insurance programs (e.g. Medicaid), and shed light on the directions for future research.

\section{Nursing Home Private-Pay Prices}

Private-pay expenditures at skilled nursing facilities represent a major financial burden for the elderly not eligible for Medicaid (Kopecky \& Koreshkova 2014). Current and continued price growth affects the affordability of nursing home care for these elderly. Out-of-pocket payments are estimated to account for $33 \%$ of formal long-term care spending among the elderly, while only $4 \%$ of the expenditure is paid through private insurance (CBO 2004; Catlin, Cowan, Stephen, \& Washington 2007). Such expenses have also been increasing drastically. For example, between 2002 and 2011, the nominal median private-pay price increased by 56.7\% in California. $^{2}$ As escalating prices depletes resources of paying seniors, more seniors will convert to Medicaid, increasing the financial burden to public funding sources.

Within the limited studies that have examined pricing in nursing homes, Stewart, Grabowski, and Lakdawalla (2009) examined the evolution of private-pay prices from 1977 to 2004 but did not explore facility or market variation in prices. Nyman (1994) used data from Wisconsin nursing homes in 1988 to show that higher market concentration of nursing homes led to higher prices. Likewise, Mukamel and Spector (2002) calculated private-pay markups above marginal costs and above Medicaid rates using a sample of FP NHs in New York State in 1991. Recent studies have shifted focus more to the relationship between public quality reporting and prices. For example, Clement, Bazzoli, and Zhao (2012) used Wisconsin nursing home data and found no effect of quality reporting on prices for medium- or high-quality homes. Among low quality homes, they found a small increase in prices and reductions in restraint use. Huang and

\footnotetext{
${ }^{2}$ Based on authors' calculation.
} 
Hirth (2016) used price information from five representative states and found that the five-star quality rating system widened the price differential between the top- and bottom-rated nursing homes. They also found a stronger price effect in less-concentrated markets where consumers are more likely to have choices of alternative nursing homes.

Relative to the existing literature, this paper uses a larger dataset, including more recent prices to study the relationship between nursing home private-pay price, organizational type, and market structure. First, both FP and nonprofit (NFP), as well as chain and nonchain nursing homes, coexist in the same markets. Differences in profit motives, tax status, quality of care, and access to resources can lead to price variations between nursing homes with different organizational types. Second, we expect that market variations in capacity and competition also will impact prices. Our paper examines the relationships between these potential determinants and nursing home private-pay price.

\section{Conceptual Framework and Hypothesis Development}

Nearly $70 \%$ of all nursing homes in the United States are FP (Schlesinger \& Gray, 2006). Because NFP organizations are restricted from sharing profits with owners and managers (Hansman, 1980), FP and NFP nursing homes are thought to be motivated differently. This has led to an abundant literature that studies the differences between FP and NFP nursing homes (e.g., Weech-Maldonado et al. 2012; Grabowski, Feng, Hirth, Rahman, \& Mor 2013). However, what is less known is how private-pay prices may differ between FP and NFP nursing homes.

Several competing hypotheses suggest a mixed relationship between FP ownership and prices. First, for the same level of quality provided, a more explicit and stronger profit motive should lead to higher prices at FP nursing homes. Second, FP nursing homes may be more efficient and have lower operating costs, which enable them to charge lower prices to gain 
market shares. Third, NFP nursing homes are exempted from business taxes and sometimes can issue tax-exempt bonds, which can lower their financing costs. These tax advantages should provide some pricing flexibility and lead to lower prices at NFP nursing homes, holding all else equal.

Last but not least, the literature found that NFP nursing homes generally provide better quality (Chou 2002; Grabowski et al. 2013). This leads to the fourth hypothesis that NFP nursing homes charge higher private-pay prices that reflect the better quality of care they provide. Synthesizing these hypotheses and opposite predictions, because several of them can occur at the same time, the net relationship between FP ownership and private-pay prices remains an empirical question. Limited by the scope of this study, we do not attempt to identify the causal mechanism that drives the price difference (if any) between FP and NFP nursing homes. Rather, our goal is to examine whether there is a statistical difference between the private-pay prices at FP and NFP nursing homes and we expect the results will serve the foundation that motivates and guides future research.

Second, more than $50 \%$ of nursing homes are affiliated to a multifacility chain and, as a result, the literature has compared chain to nonchain nursing homes for numerous outcomes, yet without studying the difference in prices (Grabowski et al. 2016; Harrington, Olney, Carrillo, \& Kang 2012; You et al. 2016). More importantly, the literature mostly focuses on FP chains and ignores the existence of NFP chains. We expect that both FP and NFP chains will have better access to resources and be better able to implement standardized practices. Therefore, in our analysis, we compare four organizational types: FP nonchains, FP chains, NFP nonchains, and NFP chains. 
In terms of market structures, because the market concentration of nursing home markets varies geographically, it creates a great opportunity to study the relationship between market concentration and price as well as whether the relationship between price and organizational types varies with market concentration. We expect that in less concentrated markets and when the availability of alternative nursing homes is greater, there will be a larger price difference with organizational type.

We also expect to see higher prices and faster price growth where markets have stricter capacity constraints. If we see larger price variations between organizational types in less capacity-constrained markets, the price variation may be the result of price competition and product differentiation of different levels of quality. In this case, price differences between organizational types are likely a reflection of different operating costs at nursing homes and, therefore, should not be of much concern. However, if we see larger price variations in markets with stricter capacity constraints, it may suggest that certain nursing homes raise prices to extract consumer surplus. In this case, it may warrant policies to relax the capacity constraints.

\section{Data and Empirical Strategies}

\section{Data}

The level and annual change of private-pay prices are the primary outcomes of interest. We extract price information from the state-administered nursing home cost reports, which we obtained from health agencies for the period 2005 through 2010 in eight states - California, Florida, Georgia, New York, Ohio, Oregon, Texas, and Vermont. Health agencies in these states collect Medicaid cost reports containing detailed and reliable information about nursing home revenues and resident payer mix. We use the annual average consumer price index to adjust for inflation in prices, and our price measure is pegged to the 2010 price level. Nursing homes in 
California, Florida, and Ohio are further required to report their revenues by routine patient care or ancillary services. The richness of information allows us to calculate daily average private-pay prices. To enhance the comparability of price information across nursing homes, when possible, we exclude ancillary revenues outside direct patient care. ${ }^{3}$ Because the cost reporting forms have slightly different classification methods, direct comparison across states should be taken with caution. ${ }^{4}$ To account for potential reporting and administrative errors, we also exclude observations with the highest and lowest $1 \%$ of private-pay price and percentages of price change. We also exclude hospital-based nursing homes because they serve different populations. Government nursing homes are also excluded. The analytic sample includes more than 3,700 unique NHs per year, equivalent to $25 \%$ of U.S. freestanding facilities. To our knowledge, our price measure closely represents the out-of-pocket expenditures borne by residents ineligible for Medicaid. We merge the price information with the LTC Focus dataset maintained by the Brown University and the Area Health Resources Files (AHRF).

\section{Empirical Methods}

We first compare prices and price growth between organizational- and market-level characteristics, including FP status, chain ownership, market competition, and proxies for capacity constraints. Second, we compare the results from two sets of regressions that control for

\footnotetext{
${ }^{3}$ We are able to have cleaner routine care prices for California, Florida, and Ohio. Private-pay price in California was calculated as the skilled nursing care revenues dividing by skilled nursing care days. Because Texas and New York reports do not separate revenues from routine and ancillary care, the direct comparison of prices across states should be taken with caution. Georgia discloses private-pay prices directly.

${ }^{4}$ Report forms are consistent within states during our study period. The detailed report form of each state is available from authors upon request.
} 
observable nursing home, market, and state characteristics. The first model utilizes the ordinary least squares regression and controls for state- and year-fixed effects. The second model includes additional county-fixed effects. Both models have their own advantages and limitations. While the county-fixed effect model is considered more statistically robust, many market-level variables of our interest have limited changes over time, and thus, the county-fixed effect model may have limited statistical power due to small variations. For completeness, we present and compare the results from both models. In addition, because FP ownership is our main variable of interest and it does not change frequently, we do not adopt a nursing home-fixed effect model and acknowledge the limitation. Overall, the baseline model is as follows:

$$
P_{i, t}=\beta_{01}+\beta_{1} * N H_{i, t}+\beta_{2} * M_{m, t}+\beta_{3} * R_{i, t}+\beta_{4} * \text { Medicaid Rate } \text { S }, t+S_{s}+T_{t}+\varepsilon_{i, t} \quad E q(1)
$$

where $P_{i, t}$ represents the average nursing home private-pay price (per day) and the annual price growth for a nursing home $i$ in year $t$. NH represents a set of NH-level variables, including the FP status, chain affiliation, FP and chain interactions (i.e. FP chain and NFP chain), occupancy rate, number of beds, and payer mix. $M$ is a set of market-level characteristics, including the Herfindahl-Hirschman Index (HHI) based on the number of beds, log-transformed median household income, local unemployment rates, and density of the elderly population. $R$ represents resident-level characteristics that are aggregated at the facility level, including racial and gender composition, age, average activities of daily living (ADL) index, and the acuity index. Medicaid Rate is the state average of Medicaid reimbursement rates. ${ }^{5} S$ and $T$ represent for state- and yearfixed effects. The standard errors are clustered at nursing homes. ${ }^{6}$

\footnotetext{
${ }^{5}$ Because the Medicaid rates are not available in 2010, we use 2009 rates in both 2009 and 2010.

${ }^{6}$ For the second specification includes count-fixed effects, the errors are clustered at county-levels.
} 


\section{Results and Discussions:}

\section{Summary Statistics}

The summary statistics are presented in Table 1 . We report the summary statistics by four organizational types. These include FP chain (column (2)), FP non-chain (column (3)), NFP chain (column (4)), and NFP nonchain (column (5)). FP and NFP nursing homes represent $80.9 \%$ and $19.1 \%$ of our sample. About $59.5 \%$ and $41.2 \%$ of the FP and NFP nursing homes are affiliated to chains. In the sample, the average real price per day and annual price growth are $\$ 197.9$ and 3.69 percentage points. Comparing the price and price growth between organizational types, on average, the NFPs have higher prices than the FPs, and chain nursing homes have lower prices than non-chain nursing homes have. In particular, FP chains have the lowest average price as of $\$ 178.6$ while NFP non-chains have the highest average price at \$242.4. NFP non-chain nursing homes also have the fastest annual price growth of $3.95 \%$ and NFP chains have the slowest price growth at $2.87 \%$. For other facility-level characteristics, FP chain-owned and NFP non-chain nursing homes have the lowest and highest occupancy rates at $83.45 \%$ and $90.71 \%$, respectively. NFP non-chain nursing homes are the largest with 144.3 beds on average, while FP chain nursing homes on average only have 109.1 beds. In terms of payer mix, FP nursing homes have significantly higher percentages of revenues from Medicaid- and Medicare-pay residents and NFP nursing homes are more dependent on private-pay residents. NFP chain nursing homes on average have $30.1 \%$ of their revenues paid by private payers, while that number is only $18.9 \%$ for the FP non-chain nursing homes. Among resident characteristics, residents at NFP nursing homes are more likely to be female, white, and older. We also find interesting differences in market structures. For example, on average, FP and NFP chains are located in areas where markets are more concentrated. The average market HHIs of FP and NFP 
chains are 0.166 and 0.162 , while market HHIs are only 0.123 and 0.122 for FP and NFP nonchain nursing homes. Both FP and NFP chain-owned nursing homes are also located in areas with lower elderly density and Medicaid reimbursement rates. Geographically, FP non-chains are disproportionately more likely located in California (32.9\%), while NFP chains are more likely located in New York (35.4\%).

\section{Prices, Organizational Types, and Market Structures}

Table 2 provides more detailed look of distributions and time trends for prices between states, organizational types, and market structures. We show the nominal price and price growth in Table 2 to facilitate comparison with general consumer and medical care price inflations. Panel A exhibits the price and price growth in each state. During the study period, the annualized inflation in general consumer and medical prices are $2.23 \%$ and $3.74 \%$ respectively. Nursing homes in New York have the highest prices. The median prices are \$260.24 in 2005 and \$309.29 in 2010. Yet, we also find slower price growth in New York. Its prices grow $18.85 \%$ from 2005 to 2010 , an annualized growth rate at $3.51 \%$. Nursing homes in Texas have the lowest median price, just \$124.14 in 2010. Among all states, during the period from 2005 through 2010, we find the fastest price growth in California and Vermont at 29.72\% and 26.54\%, respectively. In terms of annualized price growth, California and Oregon have the highest rates at $5.34 \%$ and $7.15 \%$ respectively. In Panel B, we show the price and price growth by different organizational structures. FP chains have the lowest prices and NFP non-chains have the highest prices. As in 2010 , the median prices are $\$ 188.95$ and $\$ 236.58$ respectively. Interestingly, despite having the highest prices, NFP non-chains have the slowest price growth compared to others. In Panel C, we stratify the sample by market concentration and occupancy rates. Following the guidelines issued by the Department of Justice, we first divide the sample by whether markets are more or less 
concentrated. We find a counter-intuitive result that the median price is actually higher in less concentrated markets ( $\$ 205.50$ vs. $\$ 162.56)$, and these areas also show faster price growth (4.49\% vs. $3.68 \%)$. This is probably correlated to urban-rural differences.

In addition, we find that nursing homes in markets where occupancy rates are higher than the median value have higher prices (\$209.40 vs. \$124.27) and faster price growth. The cumulative and annualized price growth are $28.78 \%$ (vs. 18.04\%) and 5.19\% (vs. 3.37\%). This suggests that under capacity constraints, both the level and growth of prices are higher and faster. Overall, comparing the descriptive statistics, we find higher prices and faster price growth in markets with capacity constraints, and that are less concentrated.

\section{Main Regression Results}

In the regression analysis, we focus on the log-transformed price and the percentage price growth. For each outcome, we run three different regressions. The first regression uses the entire sample and controls for state-fixed effects. In the second regression, we restrict the sample to nursing homes having at least five private-pay residents, equivalent to 1,825 private-pay days in a year. While nursing home residents may have different lengths of stay, this restriction implies that at least five nursing home beds are filled by private-pay residents through the year. The third regression also uses the sample with at least five private-pay residents and adds county-fixed effects. We run both the state- and county-fixed effects models because state-fixed effects allow cross-sectional variations between markets but do not account for unobservable market-level variables, and county-fixed effects control for both state- and market-unobservable factors but only allow time-series variations within markets. Each model has its own limitations and for completeness, we present both sets of results. Table 3 shows the main results. In column (1), FP non-chains had statistically significant lower prices, 2.1 percent lower than the prices of NFP 
non-chains. The county-fixed effects model (column (3)) also shows lower price but the coefficient is statistically insignificant. In terms of price growth, the negative signs of the coefficients suggest that FP non-chains may have slower price growth but the difference is not statistically insignificant (columns (4) - (6)). We also find nursing home-level occupancy rates and facility sizes were associated with higher prices but not necessarily with faster price growth.

Consistent with the summary statistics, we find statistically significant evidence that NFP chains have highest prices and FP chains have the lowest prices. We find similar but statistically weaker patterns in price growth. In terms of payer mix, higher Medicaid-pay shares are associated with lower prices but no significant relationship with price growth. When nursing homes have higher Medicare-pay shares, they have higher private-pay prices and faster price growth. A one percentage point increase in Medicare-pay share is associated with 0.19 to 0.2 percent increase in private-pay prices.

Interestingly, we find that higher market $\mathrm{HHI}$ is associated with lower prices without controlling for county-fixed effects (columns (1) and (2)). However, after controlling for countyfixed effects (column (3)), higher HHI is associated with higher prices. We don't find a statistically significant and consistent relationship in price growth (columns (4), (5), and (6)). Given that the regression specification using county-fixed effects is considered more robust and accounts for unobservable and time-invariant market-level factors, we favor the result that nursing homes prices are higher when markets are more concentrated. 


\section{The Roles of Market Structures}

In Tables 4 and 5, we report analyses on stratified samples based on the whether the market HHIs are above/below $0.15^{7}$ and whether the market-level occupancy rates are above/below the median value ( $87.63 \%)$. The goal of these analyses is to examine whether the relationship between prices and organizational types varies depending on market structures. In Table 4, we find that results of organizational types are qualitatively consistent between two strata, albeit the insignificance in the more concentrated markets may be due to a smaller sample size. In the same panel, on the other hand, we see a stronger association between facility-level occupancy rates and prices in the more concentrated markets. This finding suggests that individual nursing homes are more likely to raise prices under capacity constraints when there is limited competition from other facilities. The results of price growth in Panel B are mixed and mostly statistically insignificant. In Table 5 , we show the results of stratified samples by the market-level occupancy rates. In Panel A, we find more profound price variations between organizational types in markets that have higher median occupancy rates. Again, there is no statistically significant difference in price growth (Panel B).

\section{Discussions:}

Overall, we find that nursing home prices have consistently outpaced the general consumer and medical care inflations. We also find significant price variations between organizational types, market structures, and states. Our results suggest that NFP nursing homes, particularly NFP chains, charge statistically significant higher prices over FP nursing homes, possibly

\footnotetext{
${ }^{7}$ We use 0.15 as the cutoff value based on the Horizontal Merger Guidelines (2010) by U.S. Department of Justice and Federal Trade Commission. (https://www.justice.gov/atr/horizontal-merger-guidelines$08192010 \# 5 \mathrm{c})$
} 
associated with superior quality provided at NFP nursing homes (Chou 2002; Grabowski et al. 2013). However, this raises an important question related to the justification for the tax-exempt status that NFP nursing homes have received. Because NFP nursing homes can and do attract disproportionately more private-pay residents and also charge higher prices, it is unclear whether NFP nursing homes provide superior quality to fulfill their charitable missions and the taxexempt requirement or as a business strategy to position themselves at the high-end market segment. The significantly lower prices at FP chains also provide a different perspective that although FP chains in general have lower quality but the value of care (from the perspective of private-pay residents) may or may not be inferior to that delivered by the NFPs because of lower prices to consumers.

In addition, we find higher occupancy rates and less market competition are associated with higher prices. Although the Certificate-of-Need law is considered less binding in recent years (Grabowski, 2008), other forms of capacity regulations, both formally and informally, can still lead to excess demand for nursing home beds in selected markets. Therefore, increasing the supply of nursing home beds in markets that have high occupancy rates might help to contain price growth.

\section{Conclusions}

This paper contributes to a better understanding of nursing home price and price growth. Overall, we provide empirical evidence of the association between nursing home private-pay prices and organization types and market structures. However, we find these determinants explain relatively little about price growth. There are several limitations are worth mentioning and should be addressed in future studies. First, while we include resident characteristics to control for the differences in resident profiles, there can be unobservable and differential resident 
selection into different organization types which may bias our results. To account for this issue in future research, we suggest using resident-level data and the instrumental variables approach which theoretically can randomize the likelihood of a resident being admitted to a particular type of nursing homes. For example, researchers have used the differential distance between a nursing home resident's prior residency to the closet NFP nursing homes and to the closet FP nursing home to predict the probability of a resident choosing a NFP nursing home (Grabowski et al., 2013). Second, we do not control for quality differences between nursing homes and the observed price variations to some extent can be related to underlying quality. Future work should consider adopting structural modeling techniques that can simultaneously account for price and quality differences between nursing homes. Third, a more comprehensive price dataset including more markets and years will be useful to provide more market-level variations overtime.

Our paper shows that nursing home prices have consistently outpaced both the consumer and medical care inflations. While it may partly reflect better quality and more comprehensive services provided at nursing homes over the study period, private-pay residents still face greater financial burdens. Given the significant portion of the elderly's wealth at stake, it is important to understand whether the escalating prices mostly reflect better quality, or to some extent, are the results of market inefficiencies. In addition, we find statistically significant price differences between the FP and NFP as well as chain and non-chain nursing homes. The results suggest that when evaluating the value of nursing home care (quality over price), the private-pay price is an important factor to consider in future analyses.

\section{References}

Catlin, A., Cowan, C., Stephen, H., \& Washington, B. (2007). National health spending in 2005: The slowdown continues. Health Affairs, 26(1), 142-153. 
CBO. (2004). Financing long-term care for the elderly. CBO Paper.

CDC. (2016). Long-term care providers and services users in the United States: Data from the national study of long-term care providers, 2013-2014. Vital and Health Studies, 3:38.

Chou, S. Y. (2002). Asymmetric information, ownership and quality of care: an empirical analysis of nursing homes. Journal of Health Economics, 21(2), 293-311.

Clement, J., Bazzoli, G., \& Zhao, M. (2012). Nursing home price and quality responses to publicly reported quality information. Health Services Research, 47, 86-105.

Grabowski, D. (2008). The market for long-term care services. Inquiry, 45(1), 58-74.

Grabowski, D., Feng, Z., Hirth, R., Rahman, M., \& Mor, V. (2013). Effect of nursing home ownership on the quality of post-acute care: An instrumental variables approach. Journal of Health Economics, 32(1), 12-21.

Hansmann, H.B. (1980). The role of nonprofit enterprise. The Yale Law Journal, 89, 835-901.

Harrington, C., Olney, B., Carrillo, H., \& Kang, T. (2012). Nurse staffing and deficiencies in the largest for-profit nursing home chains and chains owned by private equity companies. Health Services Research, 47(1pt1), 106-128.

Huang, SS., \& Hirth, R. (2016). Quality Rating and Private-Prices: Evidence from the Nursing Home Industry. Journal of Health Economics, 50, 59-70.

Kopecky, K., \& Koreshkova, T. (2014). The Impact of Medical and Nursing Home Expenses on Savings. American Economic Journal: Macroeconomics, 6(3), 29-72.

Lin, H., \& Prince, J. (2013). The Impact of the Partnership Long-Term Care Insurance Program on Private Coverage. Journal of Health Economics, 32(6), 1205-1213

MedPac. (2016). Skilled Nursing Facilities Services: Assessing Payment Adequacy and Updating Payments. Report to the Congress: Medicare Payment Policy.

Mukamel, D., \& Spector, W. (2002). The Competitive Nature of the Nursing Home Industry: Price Mark Ups and Demand Elasticities. Applied Economics, 34(4), 413-420.

Nyman, J. (1994). The effect of market concentration and excess demand on the price of nursing home care. Journal of Industrial Economics, 42(2), 193-204. 
Schlesinger, M., \& Gray, B. (2006). How nonprofits matter in American medicine, and what to do about it. Health Affairs, 25(4), W287-W303.

Stewart, K., Grabowski, D., \& Lakdawalla, D. (2009). Annual expenditures for nursing home care: Private and public payer price growth, 1977 to 2004. Med Care, 47(3), 295-301.

Weech-Maldonado, R., Laberge, A., Pradhan, R., Johnson, C., Yang, Z., \& Hyer, K. (2012). Nursing home financial performance: The role of ownership and chain affiliation. Health Care Manage Rev., 37(3), 235-245.

You, K., Li, Y., Intrator, O., Stevenson, D., Hirth, R., Grabowski, D., \& Banaszak-Holl, J. (2016). Do nursing home chain size and proprietary status affect experiences with care? Med Care, 54(3), 229-234. 
Table 1. Summary Statistics

\begin{tabular}{|c|c|c|c|c|c|c|}
\hline & & All & For- & rofit & Non & rofit \\
\hline & & & Chain & Ind. & Chain & Ind. \\
\hline & & (1) & (2) & (3) & (4) & (5) \\
\hline \multirow{4}{*}{ Outcome variables } & \multirow{2}{*}{ Private price (real) } & 197.9 & 178.6 & 209.2 & 204.8 & 242.4 \\
\hline & & $(85.56)$ & $(61.12)$ & $(102.6)$ & (74.76) & $(103.1)$ \\
\hline & \multirow{2}{*}{$\%$ change of Private Price } & 3.691 & 3.642 & 3.887 & 2.872 & 3.951 \\
\hline & & $(19.88)$ & $(18.17)$ & $(22.54)$ & (17.57) & $(20.23)$ \\
\hline \multirow{10}{*}{ Facility controls } & For-profit & 0.809 & 1 & 1 & 0 & 0 \\
\hline & \multirow{2}{*}{ Occupancy rate } & 85.53 & 83.45 & 86.48 & 86.89 & 90.71 \\
\hline & & $(12.97)$ & $(14.05)$ & $(11.81)$ & $(11.40)$ & $(10.22)$ \\
\hline & \multirow{2}{*}{ \# of beds } & 116.1 & 109.1 & 118.6 & 107.9 & 144.3 \\
\hline & & $(63.26)$ & $(43.33)$ & $(64.64)$ & $(61.16)$ & $(108.2)$ \\
\hline & Chain affiliation & 0.560 & 1 & 0 & 1 & 0 \\
\hline & \multirow{2}{*}{ Medicaid-pay share (\%) } & 65.29 & 66.18 & 67.76 & 57.29 & 59.86 \\
\hline & & $(18.55)$ & $(16.78)$ & $(18.23)$ & $(22.71)$ & $(20.78)$ \\
\hline & \multirow{2}{*}{ Medicare-pay share (\%) } & 13.86 & 14.72 & 13.36 & 12.62 & 12.52 \\
\hline & & $(10.49)$ & $(10.29)$ & $(10.82)$ & $(9.023)$ & $(11.00)$ \\
\hline \multirow{14}{*}{ Patient controls } & \multirow{2}{*}{ With hypertension (\%) } & 55.75 & 55.93 & 56.44 & 54.11 & 54.09 \\
\hline & & $(15.60)$ & $(15.82)$ & $(14.82)$ & $(16.39)$ & $(16.09)$ \\
\hline & \multirow{2}{*}{ Female (\%) } & 68.77 & 67.50 & 67.45 & 73.67 & 74.58 \\
\hline & & $(14.70)$ & $(14.15)$ & $(14.69)$ & $(14.78)$ & $(14.86)$ \\
\hline & \multirow{2}{*}{ White (\%) } & 74.91 & 74.47 & 71.86 & 80.35 & 81.92 \\
\hline & & $(26.61)$ & $(25.76)$ & $(27.60)$ & $(24.59)$ & $(26.76)$ \\
\hline & \multirow{2}{*}{ Hispanic } & 5.882 & 6.064 & 7.137 & 3.180 & 3.342 \\
\hline & & $(15.38)$ & $(16.21)$ & $(15.70)$ & $(12.02)$ & $(11.96)$ \\
\hline & \multirow{2}{*}{ Avg. age } & 78.92 & 77.93 & 78.62 & 81.65 & 82.20 \\
\hline & & $(10.63)$ & $(10.25)$ & $(9.575)$ & $(11.71)$ & $(13.11)$ \\
\hline & \multirow{2}{*}{ Avg. ADL } & 16.43 & 16.30 & 16.55 & 16.38 & 16.71 \\
\hline & & $(3.345)$ & $(3.335)$ & $(3.329)$ & (3.096) & $(3.564)$ \\
\hline & \multirow{2}{*}{ Acuity index } & 11.55 & 11.53 & 11.65 & 11.42 & 11.47 \\
\hline & & $(1.332)$ & $(1.282)$ & $(1.423)$ & $(1.226)$ & $(1.325)$ \\
\hline \multirow{15}{*}{$\begin{array}{l}\text { Market/state } \\
\text { controls }\end{array}$} & \multirow{2}{*}{ HHI } & 0.147 & 0.166 & 0.123 & 0.162 & 0.122 \\
\hline & & $(0.206)$ & $(0.216)$ & $(0.193)$ & $(0.229)$ & $(0.167)$ \\
\hline & \multirow{2}{*}{$\begin{array}{l}1000 \text { s of } 65+\text { per square } \\
\text { mile }\end{array}$} & 0.234 & 0.110 & 0.320 & 0.170 & 0.559 \\
\hline & & $(0.711)$ & $(0.191)$ & $(0.782)$ & $(0.419)$ & $(1.499)$ \\
\hline & \multirow{2}{*}{ Log (household income) } & 10.78 & 10.76 & 10.81 & 10.76 & 10.79 \\
\hline & & $(0.231)$ & $(0.218)$ & $(0.245)$ & $(0.236)$ & $(0.227)$ \\
\hline & \multirow{2}{*}{ Unemp. rate } & 6.945 & 7.006 & 6.972 & 6.795 & 6.713 \\
\hline & & $(2.884)$ & $(2.886)$ & (2.948) & $(2.792)$ & $(2.728)$ \\
\hline & \multirow{2}{*}{ State Medicaid rate } & 168.3 & 158.6 & 174.3 & 168.7 & 192.3 \\
\hline & & $(35.24)$ & $(29.71)$ & $(37.00)$ & (34.14) & $(38.99)$ \\
\hline & California & 0.268 & 0.269 & 0.329 & 0.185 & 0.145 \\
\hline & Florida & 0.121 & 0.110 & 0.115 & 0.177 & 0.151 \\
\hline & Georgia & 0.0440 & 0.0580 & 0.0189 & 0.100 & 0.0177 \\
\hline & New York & 0.114 & 0.0156 & 0.181 & 0.0995 & 0.354 \\
\hline & Ohio & 0.222 & 0.251 & 0.178 & 0.256 & 0.200 \\
\hline
\end{tabular}




\begin{tabular}{|l|l|c|c|c|c|c|}
\hline & Oregon & 0.0173 & 0.0261 & 0.00663 & 0.0104 & 0.0157 \\
\cline { 2 - 7 } & Texas & 0.204 & 0.262 & 0.165 & 0.171 & 0.0968 \\
\cline { 2 - 7 } & Vermont & 0.00854 & 0.00862 & 0.00663 & 0 & 0.0197 \\
\hline Observations & & 22,141 & 10,670 & 7,244 & 1,738 & 2,489 \\
\hline
\end{tabular}

The mean and standard deviation (in parentheses) are reported for all, for-profit and chain for-profit and non-chain (independent), nonprofit and chain, nonprofit and non-chain (independent) nursing homes. 
Table 2. Median and Growth of Private-Pay Nursing Home Prices (Nominal Price)

Panel A. By States

\begin{tabular}{|c|c|c|c|c|c|c|c|c|c|c|c|}
\hline & & $\mathbf{C A}$ & FL & GA & $\mathbf{O H}$ & OR & NY & TX & VT & GeneraCPI & Medical Care CPI \\
\hline \multirow[t]{6}{*}{ Nominal price } & 2005 & 157.724 & 166.307 & N/A & 164.49 & 160.781 & 260.235 & 104.613 & 191.365 & & \\
\hline & 2006 & 167.637 & 172.72 & 135 & 172.954 & 180.806 & 269.661 & 105.044 & 197.47 & & \\
\hline & 2007 & 177.231 & 183.827 & 146.00 & 179.696 & 187.695 & 286.91 & 111.33 & 205.215 & & \\
\hline & 2008 & 186.937 & 196.972 & 152 & 187.685 & 200.693 & 292.11 & 115.602 & 219.31 & & \\
\hline & 2009 & 195.689 & 204.18 & 155 & 195.712 & 211.966 & 304.762 & 121.825 & 226.952 & & \\
\hline & 2010 & 204.6 & 209.189 & N/A & 203.032 & N/A & 309.288 & 124.139 & 242.145 & & \\
\hline \multirow[t]{6}{*}{ \% Change (year over year) } & 2006 & $6.28 \%$ & $3.86 \%$ & $\mathrm{~N} / \mathrm{A}$ & $5.15 \%$ & $12.45 \%$ & $3.62 \%$ & $0.41 \%$ & $3.19 \%$ & $3.23 \%$ & $4.00 \%$ \\
\hline & 2007 & $5.72 \%$ & $6.43 \%$ & $8.15 \%$ & $3.90 \%$ & $3.81 \%$ & $6.40 \%$ & $5.98 \%$ & $3.92 \%$ & $2.83 \%$ & $4.40 \%$ \\
\hline & 2008 & $5.48 \%$ & $7.15 \%$ & $4.11 \%$ & $4.28 \%$ & $6.93 \%$ & $1.81 \%$ & $3.84 \%$ & $6.87 \%$ & $3.86 \%$ & $3.70 \%$ \\
\hline & 2009 & $4.68 \%$ & $3.66 \%$ & $1.97 \%$ & $4.44 \%$ & $5.62 \%$ & $4.33 \%$ & $5.38 \%$ & $3.48 \%$ & $-0.37 \%$ & $3.20 \%$ \\
\hline & 2010 & $4.55 \%$ & $2.45 \%$ & N/A & $3.74 \%$ & $\mathrm{~N} / \mathrm{A}$ & $1.49 \%$ & $1.90 \%$ & $6.69 \%$ & $1.68 \%$ & $3.40 \%$ \\
\hline & 2005-2010 & $29.72 \%$ & $25.78 \%$ & $\mathrm{~N} / \mathrm{A}$ & $23.43 \%$ & $\mathrm{~N} / \mathrm{A}$ & $18.85 \%$ & $18.67 \%$ & $26.54 \%$ & $11.67 \%$ & $20.15 \%$ \\
\hline Annualized \% chg. & & $5.34 \%$ & $4.69 \%$ & $4.71 \%$ & $4.30 \%$ & $7.15 \%$ & $3.51 \%$ & $3.48 \%$ & $4.82 \%$ & $2.23 \%$ & $3.74 \%$ \\
\hline
\end{tabular}

Panel B. By Organizational Structures

\begin{tabular}{|l|l|c|c|c|c|}
\hline & & \multicolumn{2}{|c|}{ For-profit } & \multicolumn{2}{c|}{ Nonprofit } \\
\hline \multirow{5}{*}{ Nominal price } & & Chain & Ind. & Chain & Ind. \\
\cline { 2 - 6 } & $\mathbf{2 0 0 5}$ & 151.26 & 154.486 & 177.295 & 192.546 \\
\cline { 2 - 6 } & $\mathbf{2 0 0 6}$ & 155.492 & 162.829 & 173.03 & 198.74 \\
\cline { 2 - 6 } & $\mathbf{2 0 0 7}$ & 162.95 & 173.37 & 185.73 & 207.47 \\
\cline { 2 - 6 } & $\mathbf{2 0 0 8}$ & 172.231 & 182.222 & 185.496 & 216.254 \\
\cline { 2 - 6 } & $\mathbf{2 0 0 9}$ & 182.60 & 189.82 & 195.638 & 221.616 \\
\cline { 2 - 6 } & $\mathbf{2 0 1 0}$ & 188.95 & 195.47 & 225.982 & 236.575 \\
\hline \multirow{5}{*}{ chg. (YoY) } & $\mathbf{2 0 0 6}$ & $2.79 \%$ & $5.40 \%$ & $-2.41 \%$ & $3.22 \%$ \\
\cline { 2 - 6 } & $\mathbf{2 0 0 7}$ & $4.80 \%$ & $6.47 \%$ & $7.34 \%$ & $4.39 \%$ \\
\cline { 2 - 6 } & $\mathbf{2 0 0 8}$ & $5.70 \%$ & $5.11 \%$ & $-0.13 \%$ & $4.24 \%$ \\
\cline { 2 - 6 } & $\mathbf{2 0 0 9}$ & $6.02 \%$ & $4.17 \%$ & $5.47 \%$ & $2.48 \%$ \\
\cline { 2 - 6 } & $\mathbf{2 0 1 0}$ & $3.48 \%$ & $2.98 \%$ & $15.51 \%$ & $6.75 \%$ \\
\cline { 2 - 6 } & $\mathbf{2 0 0 5}-2010$ & $24.91 \%$ & $26.53 \%$ & $27.46 \%$ & $22.87 \%$ \\
\hline Annualized \% chg. & & $4.55 \%$ & $4.82 \%$ & $4.97 \%$ & $4.20 \%$ \\
\hline
\end{tabular}

Panel C. By Market Structures

\begin{tabular}{|l|l|c|c|c|c|}
\hline & & \multicolumn{2}{|c|}{ Concentration (HHI) } & \multicolumn{2}{c|}{ Mkt Occupancy } \\
\hline \multirow{4}{*}{ Nominal price } & & $<\mathbf{0 . 1 5}$ & $>=\mathbf{0 . 1 5}$ & $<$ Median & $<=$ Median \\
\cline { 2 - 6 } & $\mathbf{2 0 0 5}$ & 165 & 135.66 & 105.28 & 162.60 \\
\cline { 2 - 6 } & $\mathbf{2 0 0 6}$ & 172.65 & 137.33 & $106.28+$ & 167.38 \\
\cline { 2 - 6 } & $\mathbf{2 0 0 7}$ & 181.11 & 144.95 & 113.21 & 178.60 \\
\cline { 2 - 6 } & $\mathbf{2 0 0 8}$ & 189.99 & 148.48 & 117.90 & 188.06 \\
\cline { 2 - 6 } & $\mathbf{2 0 0 9}$ & 198.78 & 160.92 & 130.13 & 196.92 \\
\cline { 2 - 6 } \% chg. (YoY) & $\mathbf{2 0 1 0}$ & 205.497 & 162.56 & 124.27 & 209.40 \\
\cline { 2 - 6 } & $\mathbf{2 0 0 6}$ & $4.63 \%$ & $1.23 \%$ & $0.96 \%$ & $2.94 \%$ \\
\cline { 2 - 6 } & $\mathbf{2 0 0 7}$ & $4.90 \%$ & $5.54 \%$ & $6.51 \%$ & $6.71 \%$ \\
\cline { 2 - 6 } & $\mathbf{2 0 0 8}$ & $4.90 \%$ & $2.43 \%$ & $4.15 \%$ & $5.30 \%$ \\
\cline { 2 - 6 } & $\mathbf{2 0 0 9}$ & $4.63 \%$ & $8.38 \%$ & $10.37 \%$ & $4.71 \%$ \\
\cline { 2 - 6 } & $\mathbf{2 0 1 0}$ & $3.38 \%$ & $1.02 \%$ & $-4.50 \%$ & $6.34 \%$ \\
\cline { 2 - 6 } & $\mathbf{2 0 0 5 - 2 0 1 0}$ & $24.54 \%$ & $19.83 \%$ & $18.04 \%$ & $28.78 \%$ \\
\hline Annualized \% chg. & & $4.49 \%$ & $3.68 \%$ & $3.37 \%$ & $5.19 \%$ \\
\hline
\end{tabular}


Table 3. Regression Results

\begin{tabular}{|c|c|c|c|c|c|c|c|}
\hline & & \multicolumn{3}{|c|}{ Log (Price) } & \multicolumn{3}{|c|}{ \% Chg of Price } \\
\hline & & State FE All & $\begin{array}{c}\text { State FE }>5 \\
\text { Residents }\end{array}$ & $\begin{array}{c}\text { County FE }>5 \\
\text { Resdients }\end{array}$ & $\begin{array}{c}\text { State FE } \\
\text { All } \\
\end{array}$ & $\begin{array}{c}\text { State FE }>5 \\
\text { Residents }\end{array}$ & $\begin{array}{c}\text { County FE }>5 \\
\text { Resdients } \\
\end{array}$ \\
\hline & & (1) & $(2)$ & (3) & (4) & (5) & (6) \\
\hline \multirow{28}{*}{$\begin{array}{l}\text { Organizational } \\
\text { Control }\end{array}$} & \multirow{2}{*}{ For-profit } & $-0.0213 * * *$ & -0.0056 & -0.0095 & -0.6452 & -0.6437 & -0.6285 \\
\hline & & {$[0.0079]$} & {$[0.0081]$} & {$[0.0195]$} & {$[0.5700]$} & {$[0.5679]$} & {$[0.4448]$} \\
\hline & \multirow{2}{*}{$\begin{array}{l}\text { Occupancy } \\
\text { rates }\end{array}$} & $0.0004 *$ & $0.0009 * * *$ & $0.0008 * *$ & -0.0205 & 0.0066 & 0.0109 \\
\hline & & {$[0.0002]$} & {$[0.0002]$} & {$[0.0003]$} & {$[0.0174]$} & {$[0.0182]$} & {$[0.0152]$} \\
\hline & \multirow{2}{*}{ \# of beds } & $0.0005^{* * *}$ & $0.0006^{* * *}$ & $0.0005^{* * * *}$ & -0.0017 & -0.0003 & 0.0012 \\
\hline & & {$[0.0000]$} & {$[0.0000]$} & {$[0.0001]$} & {$[0.0030]$} & {$[0.0032]$} & {$[0.0032]$} \\
\hline & \multirow{2}{*}{$\begin{array}{l}\text { Nonprofit } \\
\text { chain }\end{array}$} & $0.0296 * * *$ & $0.0400 * * *$ & $0.0358 * *$ & -1.062 & -0.7299 & $-1.1714 * *$ \\
\hline & & {$[0.0096]$} & {$[0.0099]$} & {$[0.0173]$} & {$[0.6659]$} & {$[0.6547]$} & {$[0.5542]$} \\
\hline & \multirow{2}{*}{$\begin{array}{l}\text { For-profit } \\
\text { chain }\end{array}$} & $-0.0279 * * *$ & $-0.0383 * * *$ & $-0.0308^{*}$ & 0.8159 & 0.8976 & $1.4137 * *$ \\
\hline & & {$[0.0102]$} & {$[0.0106]$} & {$[0.0174]$} & {$[0.7408]$} & {$[0.7453]$} & {$[0.6101]$} \\
\hline & \multirow{2}{*}{$\begin{array}{l}\text { Medicid-pay } \\
\text { share (\%) }\end{array}$} & $-0.0013 * * *$ & $-0.0012 * * *$ & $-0.0008^{*}$ & -0.0003 & -0.0012 & -0.0035 \\
\hline & & {$[0.0002]$} & {$[0.0002]$} & {$[0.0004]$} & {$[0.0116]$} & {$[0.0126]$} & {$[0.0111]$} \\
\hline & \multirow{2}{*}{$\begin{array}{l}\text { Medicare-pay } \\
\text { share }(\%)\end{array}$} & $0.0021 * * *$ & $0.0019^{* * *}$ & $0.0019 * * *$ & $0.0494 * * *$ & $0.0312^{*}$ & $0.0285^{*}$ \\
\hline & & {$[0.0003]$} & {$[0.0003]$} & {$[0.0005]$} & {$[0.0179]$} & {$[0.0190]$} & {$[0.0168]$} \\
\hline & \multirow{2}{*}{$\begin{array}{l}\text { With hyper- } \\
\text { tension (\%) }\end{array}$} & $-0.0006^{* * *}$ & $-0.0007 * * *$ & -0.0004 & 0.001 & 0.004 & 0.0025 \\
\hline & & {$[0.0002]$} & {$[0.0002]$} & {$[0.0003]$} & {$[0.0162]$} & {$[0.0167]$} & {$[0.0166]$} \\
\hline & \multirow{2}{*}{ Female (\%) } & $0.0007 * * *$ & 0.0004 & 0.0002 & -0.0174 & -0.018 & -0.0147 \\
\hline & & {$[0.0003]$} & {$[0.0003]$} & {$[0.0005]$} & {$[0.0210]$} & {$[0.0228]$} & {$[0.0203]$} \\
\hline & \multirow{2}{*}{ White (\%) } & -0.0001 & $0.0008 * * *$ & $0.0020 * * *$ & $-0.0229 *$ & 0.0016 & 0.002 \\
\hline & & {$[0.0002]$} & {$[0.0002]$} & {$[0.0005]$} & {$[0.0126]$} & {$[0.0150]$} & {$[0.0153]$} \\
\hline & \multirow{2}{*}{ Hispanic (\%) } & 0.0003 & $0.0014^{*} * *$ & -0.0001 & 0.0091 & 0.0302 & 0.0247 \\
\hline & & {$[0.0002]$} & {$[0.0003]$} & {$[0.0006]$} & {$[0.0177]$} & {$[0.0242]$} & {$[0.283]$} \\
\hline & \multirow{2}{*}{ Avg. age } & $0.0035 * * *$ & $0.0070 * * *$ & $0.046^{* * *}$ & -0.0049 & -0.0012 & 0.004 \\
\hline & & {$[0.0006]$} & {$[0.0008]$} & {$[0.0013]$} & {$[0.0454]$} & {$[0.0559]$} & [0.0519] \\
\hline & \multirow{2}{*}{ Avg. ADL } & $0.0049 * * *$ & $0.0039 * * *$ & $0.0072 * * *$ & -0.0642 & 0.0906 & 0.076 \\
\hline & & {$[0.0011]$} & {$[0.0013]$} & {$[0.0017]$} & {$[0.0920]$} & {$[0.0957]$} & {$[0.0841]$} \\
\hline & \multirow{2}{*}{ Acuity index } & 0.001 & -0.0021 & $-0.0050^{*}$ & 0.1409 & -0.0048 & -0.074 \\
\hline & & {$[0.0020]$} & {$[0.0022]$} & {$[0.0026]$} & {$[0.1645]$} & {$[0.1618]$} & {$[0.1577]$} \\
\hline \multirow{8}{*}{ Market Control } & HHI & $-0.0747 * * *$ & $-0.1043 * * *$ & $0.1592 * * *$ & -0.3066 & 0.6419 & 15.2632 \\
\hline & HHI & {$[0.0101]$} & {$[0.0109]$} & {$[0.0527]$} & {$[0.8574]$} & {$[0.9182]$} & {$[10.1703]$} \\
\hline & 1000 s of $65+$ & $0.0445^{* * *}$ & $0.0478 * * *$ & 0.1101 & 0.2498 & 0.4504 & $30.1242 * * *$ \\
\hline & mile & {$[0.0046]$} & {$[0.0051]$} & {$[0.2415]$} & [0.4099] & {$[0.4810]$} & {$[11.5800]$} \\
\hline & Log (house- & $0.2639 * * *$ & $0.2573 * * *$ & 0.1089 & -0.3986 & 0.1237 & $27.0405^{* * *}$ \\
\hline & hold income) & {$[0.0115]$} & {$[0.0126]$} & {$[0.0696]$} & {$[0.9772]$} & {$[1.0247]$} & {$[6.6273]$} \\
\hline & Unemploy- & $0.0060 * * *$ & 0.0027 & $0.0064 * *$ & -0.1575 & $-0.2037 *$ & -0.259 \\
\hline & ment rate & {$[0.0014]$} & {$[0.0017]$} & {$[0.0029]$} & {$[0.1078]$} & {$[0.1151]$} & [0.1829] \\
\hline & Colifornia & $0.3523 * * *$ & $0.3647 * * *$ & & $3.7538 * *$ & $3.8657 * *$ & \\
\hline & California & {$[0.0183]$} & {$[0.0202]$} & & {$[1.8142]$} & {$[1.8057]$} & \\
\hline & & $0.3929 * * *$ & $0.3751 * * *$ & & $6.4369 * *$ & $6.8645 * *$ & \\
\hline & Florida & {$[0.0283]$} & {$[0.0302]$} & & {$[2.8802]$} & {$[2.9008]$} & \\
\hline & & $0.2315 * * *$ & $0.2685 * * *$ & & 0.0266 & 0.5424 & \\
\hline & Georgia & {$[0.0107]$} & {$[0.0119]$} & & [1.0383] & {$[1.0726]$} & \\
\hline State Control & Now York & $0.7206^{* * *}$ & $0.7055^{* * *}$ & & $9.1467 *$ & $9.7010 * *$ & \\
\hline State ControI & New York & {$[0.0475]$} & {$[0.0511]$} & & {$[4.7578]$} & {$[4.7930]$} & \\
\hline & & $0.4387 * * *$ & $0.4417 * * *$ & & $4.6543 * *$ & $4.6431 * *$ & \\
\hline & Ohio & {$[0.0236]$} & {$[0.0259]$} & & {$[2.2921]$} & {$[2.3052]$} & \\
\hline & & $0.5342 * * *$ & $05398 * * *$ & & $9.4259 * *$ & $11.9745^{* * *}$ & \\
\hline & Oregon & {$[0.0365]$} & {$[0.0405]$} & & {$[3.7240]$} & {$[3.7598]$} & \\
\hline & & $0.4856 * * *$ & $0.4686 * * *$ & & $5.7795 * *$ & 4.9114* & \\
\hline & Vermont & {$[0.0352]$} & {$[0.0384]$} & & {$[2.8578]$} & [2.9103] & \\
\hline \# of observations & & 22141 & 16211 & 16211 & 18194 & 13181 & 13181 \\
\hline
\end{tabular}

$*, * *$, and $* * *$, represent statistical significance at the $10 \%, 5 \%$, and $1 \%$ level 
Table 4. Subsample Analysis: Market Concentration

Panel A: $\log$ (Price)

\begin{tabular}{|c|c|c|c|c|c|c|}
\hline & \multicolumn{6}{|c|}{$\begin{array}{l}\text { Log (Price) } \\
\end{array}$} \\
\hline & $\begin{array}{c}\text { State FE All } \\
\text { HHI }<0.15\end{array}$ & $\begin{array}{c}\text { State FE All } \\
\text { HHI }>0.15\end{array}$ & $\begin{array}{c}\text { State FE }>5 \\
\text { Residents } \\
\text { HHI }<0.15\end{array}$ & $\begin{array}{c}\text { State FE }>5 \\
\text { Residents } \\
\text { HHI }>0.15\end{array}$ & $\begin{array}{c}\text { County FE }>5 \\
\text { Residents } \\
\text { HHI }<0.15\end{array}$ & $\begin{array}{c}\text { County FE }>5 \\
\text { Residents } \\
\text { HHI }>0.15\end{array}$ \\
\hline & (1) & (2) & (3) & (4) & (5) & (6) \\
\hline \multirow[t]{2}{*}{ For-profit } & $-0.0215^{* *}$ & -0.0207 & -0.0019 & -0.0131 & -0.0071 & -0.0165 \\
\hline & {$[0.0095]$} & {$[0.0144]$} & {$[0.0097]$} & [0.0149] & {$[0.0228]$} & {$[0.0296]$} \\
\hline \multirow{2}{*}{$\begin{array}{l}\text { Nonprofit } \\
\text { chain }\end{array}$} & $0.0240^{* *}$ & $0.0462^{* * *}$ & $0.0416^{* * *}$ & $0.0386 * *$ & $0.0386^{*}$ & 0.0272 \\
\hline & {$[0.0117]$} & {$[0.0162]$} & {$[0.0122]$} & {$[0.0164]$} & {$[0.0209]$} & {$[0.0279]$} \\
\hline \multirow{2}{*}{$\begin{array}{l}\text { For-profit } \\
\text { chain }\end{array}$} & $-0.0245^{* *}$ & $-0.0322 *$ & $-0.0378 * * *$ & -0.0279 & -0.0321 & -0.0251 \\
\hline & {$[0.0125]$} & {$[0.0172]$} & {$[0.0132]$} & {$[0.0175]$} & {$[0.0203]$} & {$[0.0327]$} \\
\hline \multirow{2}{*}{$\begin{array}{l}\text { Occupancy } \\
\text { rate }\end{array}$} & 0 & $0.0012^{* * *}$ & $0.0006^{* *}$ & $0.0016^{* * *}$ & 0.0006 & $0.0016^{* * *}$ \\
\hline & {$[0.0002]$} & {$[0.0003]$} & {$[0.0003]$} & {$[0.0003]$} & {$[0.0004]$} & {$[0.0005]$} \\
\hline \multirow{2}{*}{$\begin{array}{l}\text { Medicid-pay } \\
\text { share (\%) }\end{array}$} & $-0.0016^{* * * *}$ & $0.0007^{*}$ & $-0.0014 * * *$ & 0.0003 & $-0.0009^{*}$ & 0.0005 \\
\hline & {$[0.0002]$} & {$[0.0004]$} & {$[0.0002]$} & {$[0.0005]$} & {$[0.0005]$} & {$[0.0008]$} \\
\hline \multirow{3}{*}{$\begin{array}{l}\text { Medicare-pay } \\
\text { share (\%) } \\
\text { \# of observations }\end{array}$} & $0.0017 * * *$ & $0.0028^{* * *}$ & $0.0017 * * *$ & $0.0016^{* *}$ & $0.0019 * * *$ & 0.0015 \\
\hline & {$[0.0003]$} & {$[0.0006]$} & {$[0.0003]$} & {$[0.0007]$} & {$[0.0005]$} & {$[0.0011]$} \\
\hline & 15704 & 6437 & 11033 & 5178 & 11033 & 5178 \\
\hline
\end{tabular}

Panel B: \% Chg. Of Private Price

\begin{tabular}{|c|c|c|c|c|c|c|}
\hline & \multicolumn{6}{|c|}{ \% Chg of Price } \\
\hline & $\begin{array}{c}\text { State FE All } \\
\text { HHI }<0.15\end{array}$ & $\begin{array}{c}\text { State FE All } \\
\text { HHI }>0.15\end{array}$ & $\begin{array}{c}\text { State FE }>5 \\
\text { Residents } \\
\text { HHI }<0.15\end{array}$ & $\begin{array}{c}\text { State FE }>5 \\
\text { Residents } \\
\text { HHI }>0.15\end{array}$ & $\begin{array}{c}\text { County FE }>5 \\
\text { Residents } \\
\text { HHI }<0.15\end{array}$ & $\begin{array}{c}\text { County FE }>5 \\
\text { Residents } \\
\text { HHI }>0.15\end{array}$ \\
\hline & (1) & (2) & (3) & (4) & (5) & $(6)$ \\
\hline \multirow[t]{2}{*}{ For-profit } & -0.6014 & -0.7483 & -0.6362 & -0.6291 & -0.5936 & -0.8664 \\
\hline & [06722] & [1.0749] & {$[0.6869]$} & {$[1.0007]$} & {$[0.4763]$} & [1.1372] \\
\hline \multirow{2}{*}{$\begin{array}{l}\text { Nonprofit } \\
\text { chain }\end{array}$} & -1.2567 & -0.932 & -0.9611 & -0.3279 & $-1.3155^{* *}$ & -0.7328 \\
\hline & {$[0.7936]$} & [1.2629] & {$[0.8020]$} & [1.1453] & {$[0.6311]$} & [1.1777] \\
\hline \multirow{2}{*}{$\begin{array}{l}\text { For-profit } \\
\text { chain }\end{array}$} & 1.1768 & 0.3776 & 1.2817 & 0.3231 & $1.7516^{* *}$ & 0.5681 \\
\hline & {$[0.8867]$} & [1.3897] & {$[0.9202]$} & {$[1.2780]$} & {$[0.7008]$} & {$[1.2996]$} \\
\hline \multirow{2}{*}{$\begin{array}{l}\text { Occupancy } \\
\text { rate }\end{array}$} & $-0.0361^{*}$ & 0.0015 & 0.0048 & 0.0236 & -0.0022 & 0.0394 \\
\hline & {$[0.0208]$} & {$[0.0252]$} & {$[0.0220]$} & {$[0.0258]$} & {$[0.0175]$} & {$[0.0288]$} \\
\hline \multirow{2}{*}{$\begin{array}{l}\text { Medicid-pay } \\
\text { share (\%) }\end{array}$} & -0.007 & 0.0233 & -0.005 & 0.0174 & -0.0056 & 0.0097 \\
\hline & {$[0.0130]$} & {$[0.0287]$} & {$[0.0144]$} & {$[0.0294]$} & {$[0.0118]$} & {$[0.0330]$} \\
\hline \multirow{2}{*}{$\begin{array}{l}\text { Medicare-pay } \\
\text { share (\%) }\end{array}$} & $0.0396^{* *}$ & $0.1003^{* *}$ & 0.0293 & 0.0388 & 0.0285 & 0.0311 \\
\hline & {$[0.0196]$} & {$[0.0445]$} & [0.0211] & {$[0.0442]$} & {$[0.0178]$} & [0.0495] \\
\hline \# of observations & 12969 & 5225 & 8989 & 4192 & 8989 & 4192 \\
\hline
\end{tabular}

All regressions include the same control variables as in Table 3.

$*, * *$, and $* * *$, represent statistical significance at the $10 \%, 5 \%$, and $1 \%$ level. 
Table 5. Market-Level Occupancy Rates

Panel A: Log (Price)

\begin{tabular}{|c|c|c|c|c|c|c|}
\hline & \multicolumn{6}{|c|}{ Log (Price) } \\
\hline & $\begin{array}{c}\text { State FE All } \\
\text { Occup }< \\
\text { Median }\end{array}$ & $\begin{array}{c}\text { State FE All } \\
\text { Occup > } \\
\text { Median }\end{array}$ & $\begin{array}{c}\text { State FE }>5 \\
\text { Residents } \\
\text { Occup }< \\
\text { Median } \\
\end{array}$ & $\begin{array}{c}\text { State FE }>5 \\
\text { Residents } \\
\text { Occup }> \\
\text { Median } \\
\end{array}$ & $\begin{array}{c}\text { County FE }>5 \\
\text { Residents } \\
\text { Occup }< \\
\text { Median } \\
\end{array}$ & $\begin{array}{c}\text { County FE }>5 \\
\text { Residents } \\
\text { Occup }> \\
\text { Median } \\
\end{array}$ \\
\hline & (1) & (2) & (3) & (4) & (5) & (6) \\
\hline \multirow[t]{2}{*}{ For-profit } & $-0.0981 * * *$ & $0.0223 * *$ & $-0.0799 * * *$ & $0.0357 * * *$ & $-0.0796 * * *$ & 0.0332 \\
\hline & {$[0.0123]$} & {$[0.0103]$} & {$[0.0117]$} & {$[0.0108]$} & {$[0.0199]$} & {$[0.0248]$} \\
\hline \multirow{2}{*}{$\begin{array}{l}\text { Nonprofit } \\
\text { chain }\end{array}$} & 0.0072 & $0.325 * *$ & 0.0205 & $0.0478 * * *$ & 0.0133 & $0.0465^{*}$ \\
\hline & {$[0.0131]$} & {$[0.0134]$} & {$[0.0126]$} & {$[0.0139]$} & {$[0.0196]$} & {$[0.0238]$} \\
\hline \multirow{2}{*}{$\begin{array}{l}\text { For-profit } \\
\text { chain }\end{array}$} & 0.0213 & $-0.0500 * * *$ & 0.0053 & $-0.0574 * * *$ & 0.0128 & $-0.0562 * *$ \\
\hline & {$[0.0141]$} & {$[0.0142]$} & {$[0.0139]$} & {$[0.0150]$} & {$[0.0211]$} & {$[0.0226]$} \\
\hline \multirow{2}{*}{$\begin{array}{l}\text { Medicid-pay } \\
\text { share (\%) }\end{array}$} & $-00018 * * *$ & $-0.0007 * * *$ & $-0.0016^{* * *}$ & -0.0005 & $-0.0014 * * *$ & -0.0002 \\
\hline & {$[0.0002]$} & {$[0.0003]$} & {$[0.0003]$} & {$[0.0003]$} & {$[0.0004]$} & {$[0.0007]$} \\
\hline \multirow{2}{*}{$\begin{array}{l}\text { Medicare-pay } \\
\text { share (\%) }\end{array}$} & $0.0024 * * *$ & $0.0017 * * *$ & $0.0018 * * *$ & $0.0019 * * *$ & $0.0020 * * *$ & $0.0019 * * *$ \\
\hline & {$[0.0004]$} & {$[0.0003]$} & {$[0.0004]$} & {$[0.0004]$} & {$[0.0006]$} & {$[0.0007]$} \\
\hline \multirow[t]{2}{*}{ HHI } & $-0.01415 * * *$ & $-0.0929 * * *$ & $-0.0355 * * *$ & $-0.1351 * * *$ & $0.2385 * *$ & 0.0832 \\
\hline & {$[0.0134]$} & {$[0.0160]$} & {$[0.0138]$} & {$[0.0184]$} & {$[0.0953]$} & {$[0.0606]$} \\
\hline \# of observations & 11021 & 11120 & 7882 & 8329 & 7882 & 8329 \\
\hline
\end{tabular}

Panel B: \% Chg. Of Private Price

\begin{tabular}{|c|c|c|c|c|c|c|}
\hline & \multicolumn{6}{|c|}{ \% Chg of Price } \\
\hline & $\begin{array}{c}\text { State FE All } \\
\text { Occup }< \\
\text { Median }\end{array}$ & $\begin{array}{c}\text { State FE All } \\
\text { Occup > } \\
\text { Median }\end{array}$ & $\begin{array}{c}\text { State FE }>5 \\
\text { Residents } \\
\text { Occup }< \\
\text { Median }\end{array}$ & $\begin{array}{c}\text { State FE }>5 \\
\text { Residents } \\
\text { Occup }> \\
\text { Median }\end{array}$ & $\begin{array}{c}\text { County FE }>\mathbf{5} \\
\text { Residents } \\
\text { Occup }< \\
\text { Median }\end{array}$ & $\begin{array}{c}\text { County FE }>5 \\
\text { Residents } \\
\text { Occup }> \\
\text { Median }\end{array}$ \\
\hline & (1) & (2) & (3) & (4) & (5) & $(6)$ \\
\hline \multirow[t]{2}{*}{ For-profit } & 0.1815 & -1.1945 & 0.0448 & -1.237 & -0.6483 & -0.7709 \\
\hline & {$[0.8975]$} & {$[0.7365]$} & {$[0.8552]$} & {$[0.7542]$} & {$[0.7322]$} & {$[0.6226]$} \\
\hline \multirow{2}{*}{$\begin{array}{l}\text { Nonprofit } \\
\text { chain }\end{array}$} & -0.8449 & -0.9631 & -0.4089 & -0.8119 & $-1.6324 * *$ & -0.6681 \\
\hline & [0.9929] & [0.9094] & [0.9192] & [0.9315] & {$[0.8025]$} & {$[0.8867]$} \\
\hline \multirow{2}{*}{$\begin{array}{l}\text { For-profit } \\
\text { chain }\end{array}$} & -0.0053 & 1.4208 & -0.1535 & $1.9813^{*}$ & 1.2245 & $1.7444^{*}$ \\
\hline & {$[1.1045]$} & {$[1.0049]$} & {$[1.0621]$} & {$[1.0436]$} & {$[0.9040]$} & {$[0.9488]$} \\
\hline \multirow{2}{*}{$\begin{array}{l}\text { Medicid-pay } \\
\text { share (\%) }\end{array}$} & -0.0157 & 0.0136 & -0.0049 & 0.0027 & 0.0063 & -0.0087 \\
\hline & {$[0.0174]$} & [0.0159] & {$[0.0181]$} & {$[0.0178]$} & {$[0.0172]$} & {$[0.0158]$} \\
\hline \multirow{2}{*}{$\begin{array}{l}\text { Medicare-pay } \\
\text { share (\%) }\end{array}$} & $0.0754 * * *$ & 0.0268 & $0.0688 * *$ & 0.0018 & $0.0752 * * *$ & -0.0031 \\
\hline & {$[0.0281]$} & {$[0.0230]$} & {$[0.0304]$} & {$[0.0242]$} & {$[0.0284]$} & {$[0.0230]$} \\
\hline \multirow[t]{2}{*}{ HHI } & 0.3798 & -0.3703 & 1.034 & 0.3387 & 29.7808 & 5.7563 \\
\hline & {$[1.2582]$} & [1.1273] & {$[1.3761]$} & [1.1877] & {$[19.2918]$} & [5.0453] \\
\hline \# of observations & 9427 & 8767 & 6668 & 6513 & 6668 & 6513 \\
\hline
\end{tabular}

All regressions include the same control variables as in Table 3.

$*$, **, and $* * *$, represent statistical significance at the $10 \%, 5 \%$, and $1 \%$ level. 